\title{
OVERVIEW OF THE NEW 1:25,000-SCALE GEOLOGIC MAPPING OF THE MCCALLUM-SLATE CREEK FAULT SYSTEM, EASTERN ALASKA RANGE, ALASKA
}

R.J. Gillis, P.G. Fitzgerald, K.D. Ridgway, B.M. Keough, J.A. Benowitz, W.K. Allen

\section{Preliminary Interpretive Report 2018-3}

This publication is PRELIMINARY in nature and meant to allow rapid release of field observations or initial interpretations of geology or analytical data. It has undergone limited peer review, but does not necessarily conform to DGGS editorial standards. Interpretations or conclusions contained in this publication are subject to change.

2019

STATE OF ALASKA DEPARTMENT OF NATURAL RESOURCES DIVISION OF GEOLOGICAL \& GEOPHYSICAL SURVEYS

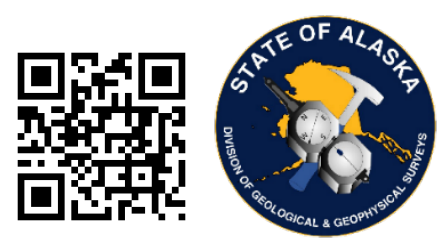


STATE OF ALASKA

Michael J. Dunleavy, Governor

DEPARTMENT OF NATURAL RESOURCES

Corri A. Feige, Commissioner

DIVISION OF GEOLOGICAL \& GEOPHYSICAL SURVEYS

Steve Masterman, State Geologist \& Director

Publications produced by the Division of Geological \& Geophysical Surveys are available to download from the DGGS website (dggs.alaska.gov). Publications on

hard-copy or digital media can be examined or purchased in the Fairbanks office:

\section{Alaska Division of Geological \& Geophysical Surveys (DGGS)}

3354 College Road | Fairbanks, Alaska 99709-3707

Phone: 907.451 .5010 | Fax 907.451.5050

dggspubs@alaska.gov $\mid$ dggs.alaska.gov

DGGS publications are also available at:

Alaska State Library, Historical

Collections \& Talking Book Center

395 Whittier Street

Juneau, Alaska 99801

Alaska Resource Library and

Information Services (ARLIS)

3150 C Street, Suite 100

Anchorage, Alaska 99503

\section{Suggested citation:}

Gillis, R.J., Fitzgerald, P.G., Ridgway, K.D., Keough, B.M., Benowitz, J.A., and Allen, W.K., 2019, Overview of the new 1:25,000-scale geologic mapping of the McCallum-Slate Creek fault system, Eastern Alaska Range, Alaska: Alaska Division of Geological \& Geophysical Surveys Preliminary Interpretive Report 2018-3, 9 p. http://doi.org/10.14509/30136
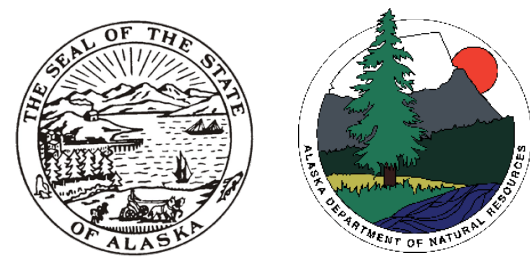


\section{OVERVIEW OF NEW 1:25,000-SCALE GEOLOGIC MAPPING OF THE MCCALLUM- SLATE CREEK FAULT SYSTEM, EASTERN ALASKA RANGE, ALASKA}

R.J.Gillis, ${ }^{1}$ P.G. Fitzgerald, ${ }^{2}$ K.D. Ridgway, ${ }^{3}$ B.M. Keough, ${ }^{3}$ J.A. Benowitz, ${ }^{4}$ W.K. Allen ${ }^{3}$

\section{INTRODUCTION}

The Alaska Division of Geological \& Geophysical Surveys (DGGS) is collaborating with the University of Alaska, Fairbanks (UAF), Purdue, and Syracuse Universities on a multidisciplinary geologic field project funded by the National Science Foundation to study the role of the continental-scale strike-slip Denali fault and its subsidiary structures in the formation and evolution of the eastern Alaska Range. The scientific objectives of this project include evaluating the relative roles of contrasting terrane rheology (on a large scale) vs fault geometry (e.g. Fitzgerald and others 2014). A variety of approaches including thermochronology and basin analysis, as well as DGGS-led mapping, is being employed. Remote field work was completed from 2015 through 2018 and focused on geology associated with the McCallum-Slate Creek fault system (MSCFS), an important composite structure that constitutes part of the Denali fault system. DGGS' role in the study was to map approximately 30 square miles (78 square $\mathrm{km}$ ) of the MSCFS from the east side of the Gulkana Glacier to the East Fork of the Chistochina River at 1:25,000-scale (fig. 1). Although the focus of the project is largely scientific, the results are important for developing a more robust geologic framework in a region of the state that has potential or proven economic hydrocarbon and minerals resources.

The MSCFS is composed of a family of Cenozoic faults that extend for nearly 40 miles $(64 \mathrm{~km})$ from the Richardson Highway near Rainbow Ridge southeastward to the commercial gold mining area of Slate Creek (fig. 1), and are genetically related to the seismically active Denali-Totschunda fault system (see Ratchkovski, 2003). The MSCFS has been variably mapped in the past as a collection of contractional, extensional, and strike-slip faults that locally define the southwestern boundary of the eastern Alaska Range and northeastern boundary of the Copper River basin (CRB); a frontier basin that is currently being explored for natural gas. Cenozoic strata that are discontinuously and incompletely exposed at the periphery of the CRB potentially are proximal examples of correlative distal facies in the basin subsurface, and therefore provide the only opportunity for their direct study. For instance, faulted-bounded early Eocene sedimentary rocks exposed at the surface along the MSCFS are juxtaposed against Miocene through Pleistocene(?) strata that dip into the CRB subsurface. Yet, previous inch-to-mile (1:63,360-scale) geologic map interpretations of the MSCFS (Hanson, 1963; Rose, 1967; Bond, 1976; Foley and Summers, 1990; Nokleberg and others, 2015) often conflict due to their reconnaissance nature, and a synthesis of how the southern foothills of the eastern Alaska Range and CRB margin evolved with time is only beginning to emerge (for example Allen and others, 2015, 2016, 2018; Waldien and others, 2018). The new, more detailed 1:25,000-scale geologic mapping by DGGS not only resolves inconsistencies between earlier maps, but also lends new insights into slip partitioning on the Denali

\footnotetext{
${ }^{1}$ Alaska Division of Geological \& Geophysical Surveys, 3354 College Rd., Fairbanks, AK 99709

${ }^{2}$ Department of Earth Sciences, Syracuse University, 204 Heroy Geology Laboratory, Syracuse, NY 13244

${ }^{3}$ Earth, Atmospheric, and Planetary Sciences, Purdue University, 550 Stadium Mall Drive, West Lafayette, IN 47906

${ }^{4}$ Geophysical Institute and Geochronology Laboratory, University of Alaska Fairbanks, Fairbanks, AK 99775
} 


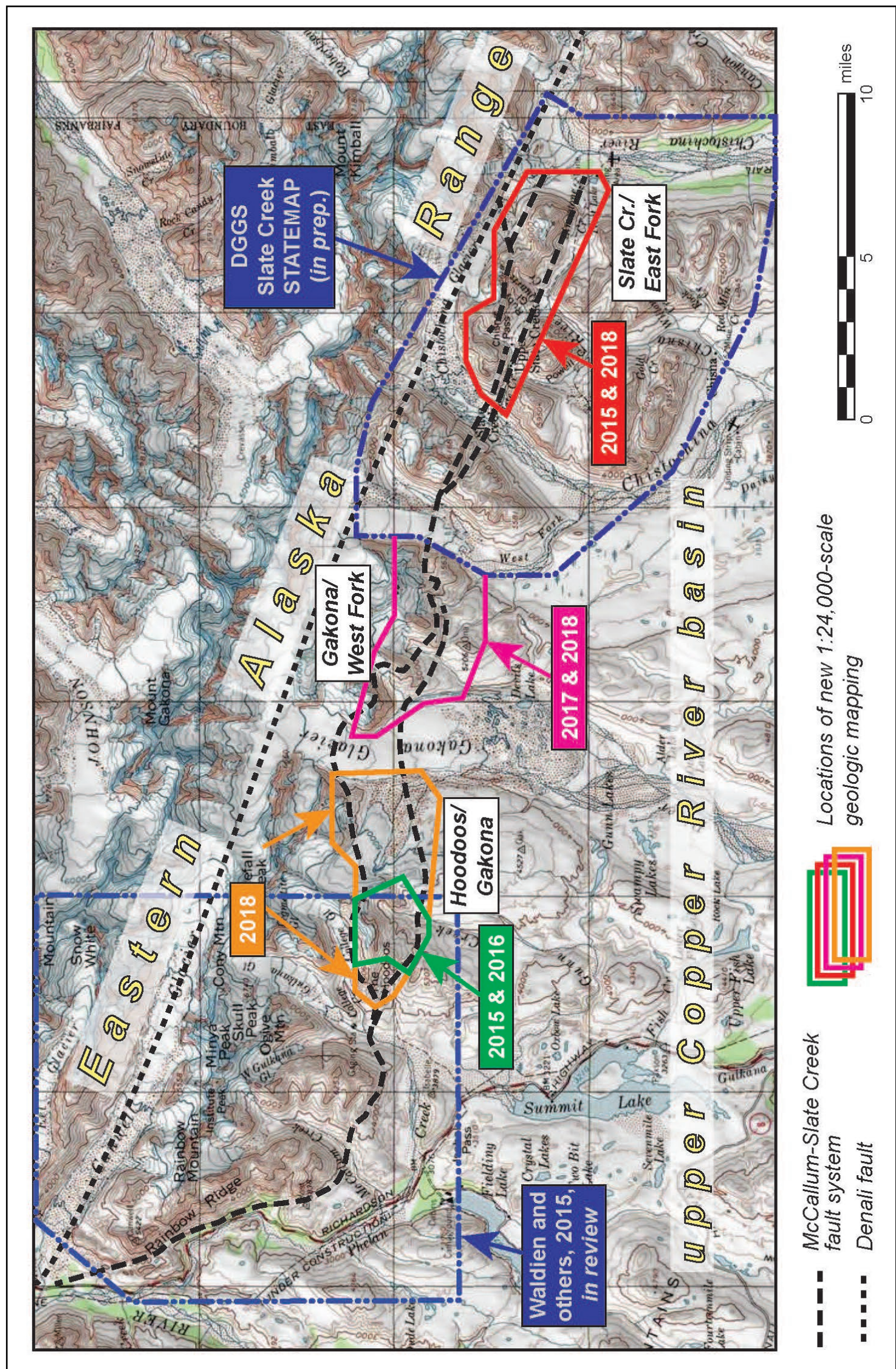

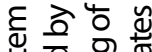

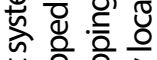

늘 을 웧

눙

ऽ $\frac{10}{0}$ 응

范

ज़

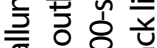

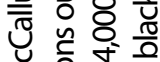

$\sum$ 旅

要

응 항

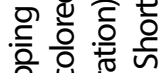

흘 흥

는

을

o

$\frac{0}{5}$

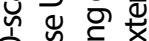

8 这

令空

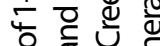

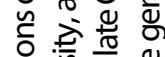

需

ช.

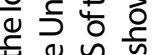

夏票哥

호을

잉

ज证

을 흥 웡

赵

语

这遂

둥

政 on

\%

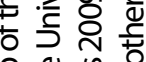

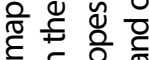

㛈

응

잉. 음

응 응 을

政

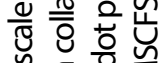

은 돈

응 或

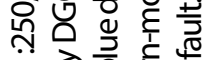

증응 홍

可哥

言岕㲾㲾 
fault system with time (Benowitz and others, 2012; Waldien and others, 2018). The findings will be integrated with recent 1:24,000-scale geologic mapping of the MSCFS to the northwest (Waldien and others, 2018) and collaborative stratigraphic, sediment provenance, and thermochronologic results from this study (for example, Allen and others, 2016, 2018; Fitzgerald and others, 2017; Warfel and others, 2018, respectively), to improve the understanding of eastern Alaska Range construction and contemporaneous subsidence and deposition in the adjacent CRB.

\section{OBSERVATIONSAND PRELIMINARY INTERPRETATIONS}

Key to unraveling the deformation history of the southern foothills of the eastern Alaska Range is the identification and understanding of cross-cutting fault relationships in the MSCFS. Preliminary interpretation of new mapping and field observations are anchored by new 40Ar/39Ar, zircon $\mathrm{U}-\mathrm{Pb}$, and palynologic ages to be published in a subsequent report. They include (i) initial syn-depositional early Eocene extension or transtension. (ii) Post-Oligocene contraction recorded by Mesozoic and Paleozoic bedrock that are thrust over Paleogene basin strata along low angle faults. (iii) Post-late Miocene contractional or transpressional reactivation of higher-angle extensional structures locally place early Eocene sedimentary and volcanics rocks against late Miocene strata. Elsewhere, reactivation of these high angle faults may cut the low-angle bedrockinvolved thrusts.

Evidence for early Eocene extension and subsequent contractional inversion of the extensional basin is best expressed in the Hoodoos-Gakona area (fig. 2). There, the east-west striking, moderately northeastwarddipping $\left(45-50^{\circ}\right)$ McCallum Creek fault originally formed the southwestern structural boundary of a Paleogene pull-apart basin. In this area, the exhumed basin is preserved in a hanging-wall syncline and further deformed by intra-basin faults that place matrix-supported early Eocene conglomerate and sandstone with northward-fanning growth strata in normal contact against an older Eocene volcaniclastic unit. The McCallum Creek fault contact is intruded along much of its length by an early Eocene basalt dike up to 1300 feet (400 meters) wide. Although the unit ages are preliminary, their close association in time suggests coeval extension, volcanism, and deposition of the siliclastic and volcaniclastic rocks that compose the basin fill (fig. 3).Post-Oligocene contraction is demonstrated in the iconic Hoodoo region, where Permian and Triassic bedrock is thrust over the northwest corner of the Eocene basin along a shallowly north-northwest-dipping fault. After late Miocene time, bedrock and basin fill that constitute the hanging-wall of the McCallum Creek fault are placed against locally folded and southwestward-tilted late Miocene strata that plunge into the CRB subsurface, recording contractional reactivation of the extensional structures and inversion of the early Eocene basin after late Miocene time. Glacial till overlying Miocene strata are tilted at approximately the same attitude, suggesting a blind contractional structure distal to the McCallum Creek fault deformed both packages of rocks simultaneously as recently as Pleistocene(?) time (see also Waldien and others, 2015; 2018).

Many of the basic geologic and structural relationships observed in the Hoodoos-Gakona area persist along

strike to the southeast in the Gakona-West Fork and Slate Creek-East Fork regions (fig. 1), although fault 


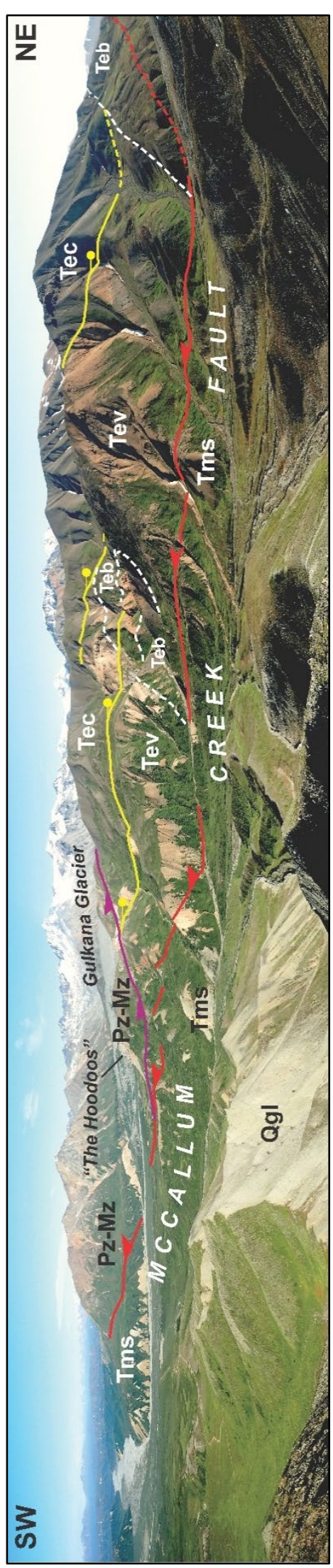

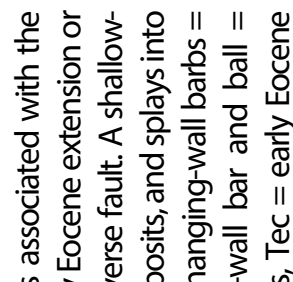

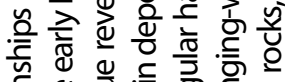

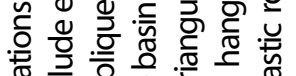

는

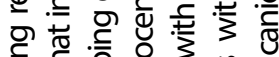

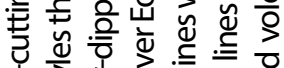

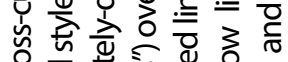

은 牙

를 웡 은

语

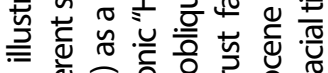

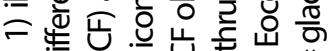

क원

\&

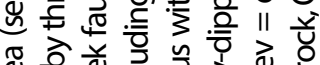

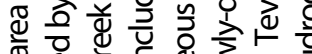

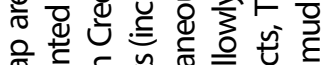

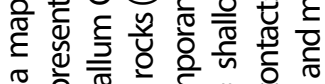

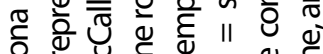

卷

语

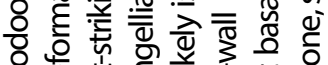

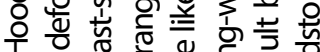

ष

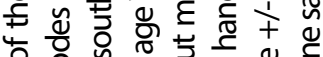

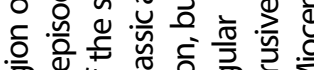

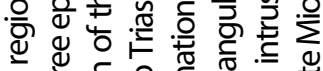

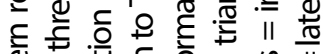

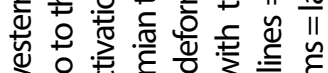

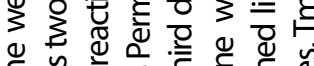

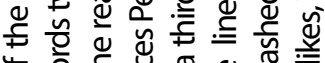

प

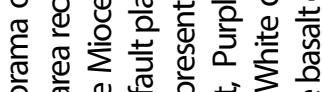

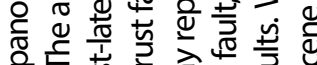

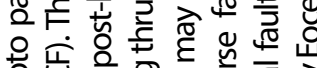

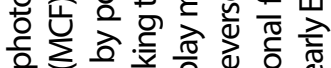

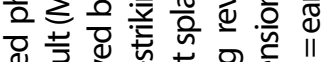

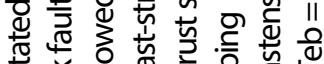

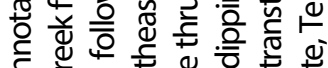

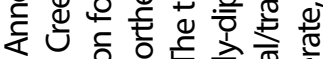

츤 은

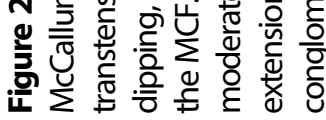




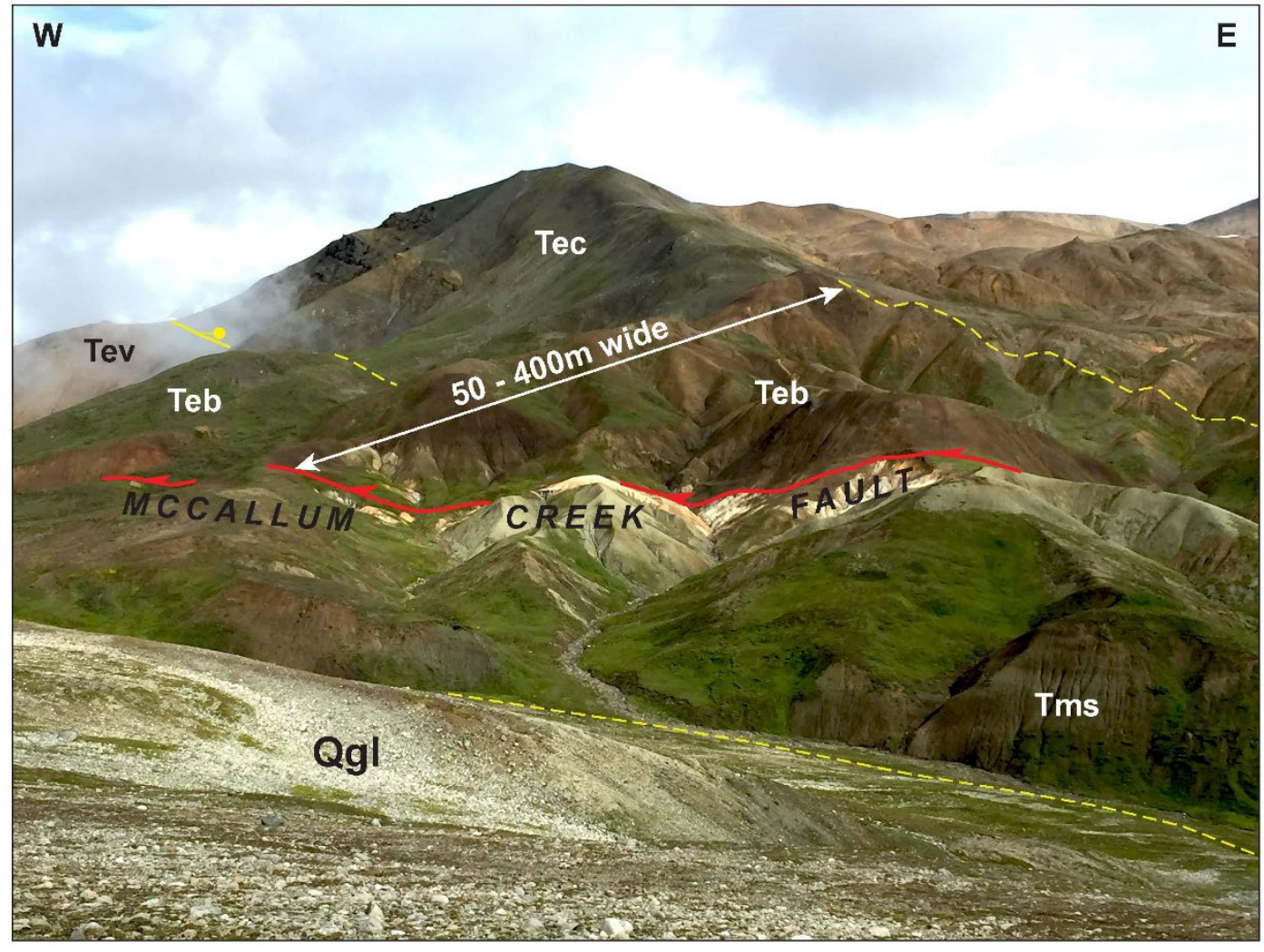

Figure 3. Early Eocene basalt dike (Teb) in the Hoodoos-Gakona map area to the southeast of fig. 2. The dike marks the McCallum Creek fault (MCF) contact between early Eocene (Tev, Tec) and late Miocene(Tms) strata and is interpreted to be synextensional. It is faulted against, and locally intrudes, a proximal conglomerate unit (Tec) at its northeastern boundary for $\sim 2$ miles (3.2 km), where it varies in thickness from $\sim 525-1,300 \mathrm{ft}$ (160-400 m). The dike is faulted against late Miocene strata along its southwestern boundary. To the northwest (fig. 2), the dike is discontinuous, but associated with faulted Eocene strata near the Miocene MCF contact.

orientations and cross-cutting relationships are often more difficult to interpret because the fault contacts are not well exposed. Characteristics common along the entire MSCFS mapped for this study include discontinuous occurrences of Cenozoic strata that are chiefly deformed by moderately- to steeply-dipping structures subparallel to the northwest-striking Denali fault, and low-angle faults that commonly strike east-west at an oblique angle to the Denali fault that locally thrust bedrock over Paleogene basin strata. Normal separation is common where fault cutoff relationships are resolvable for higher-angle structures between the Gakona Glacier and East Fork of the Chistochina River, although the magnitude of strike-slip along the faults remains poorly constrained. Mesozoic and Paleozoic bedrock are thrust a minimum of $1 / 2$ mile $(0.8 \mathrm{~km})$ over Oligocene and Eocene strata in the Gakona-West Fork and Slate Creek-East Fork regions (fig. 4), respectively, and are locally dissected by later high-angle faulting, potentially during reactivation of earlier extensional faults.

Initial conclusions from geologic mapping and field observations suggest a major change in the state of stress in the MSCFS just south of the Denali fault from transtension accompanied by mafic to intermediate 


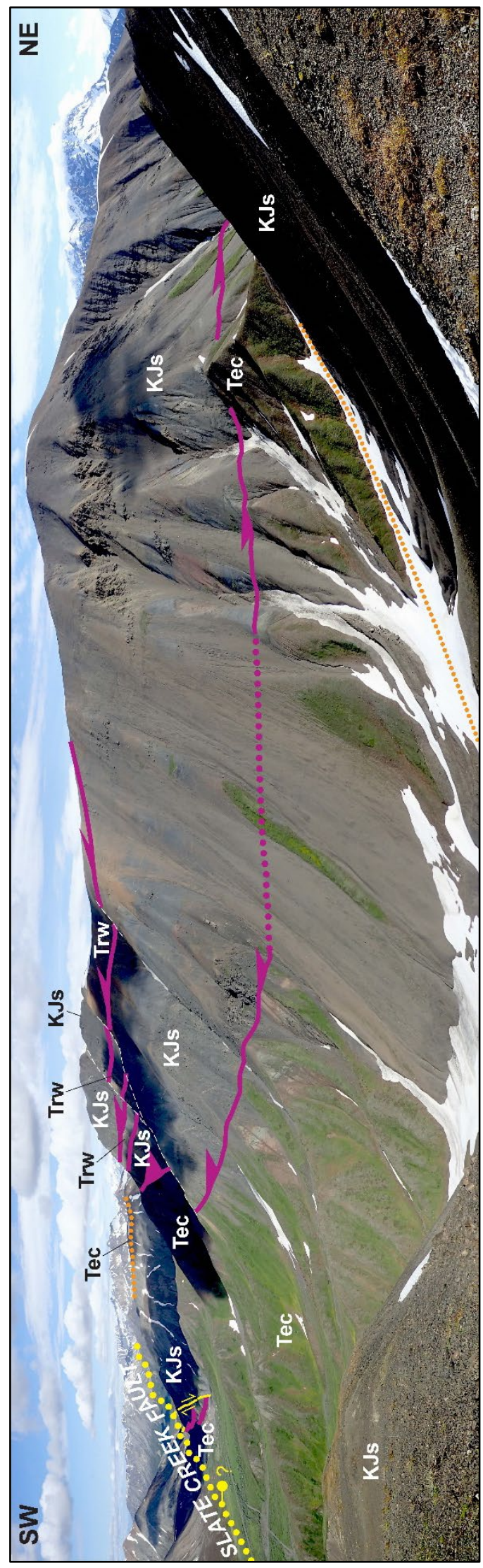

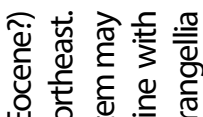

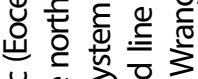
늠 至焉 웡

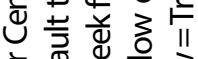

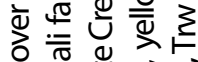

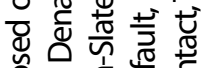
음 은 흔

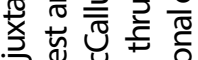
\% 专

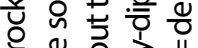
凹 등 충

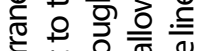

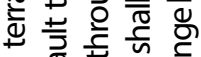
은

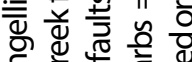

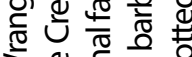
范

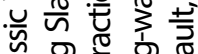

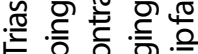
드응 흥 음 웅

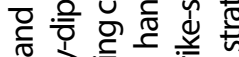

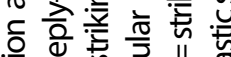
윰

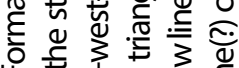
안 全

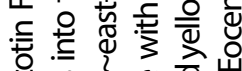

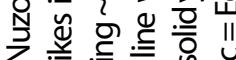

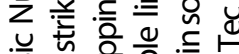

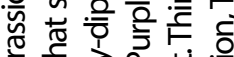

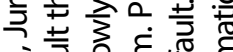

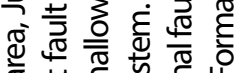

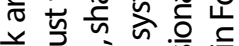
ये

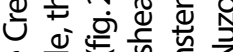

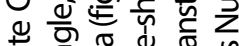

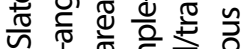

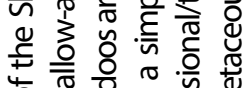
呟

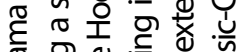

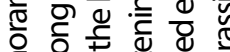

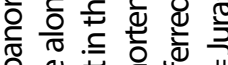

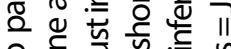

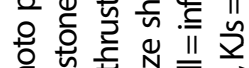

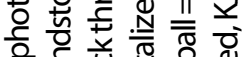

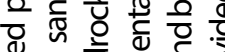

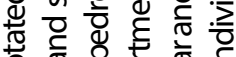
응

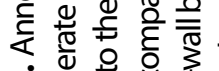
ชं

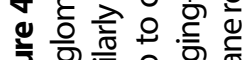

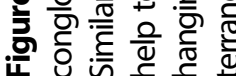


volcanism and clastic sedimentation in the early Eocene to dextral transpression in the absence of major volcanic activity after Oligocene time. Structurally-controlled subsidence driven by transtension along the MSCFS preserve relatively thick packages of volcanic, volcaniclastic rocks and proximal cobble to boulder conglomerate. These sediment packages are important because they include the "roundwash" at Slate Creek (fig. 4), that has produced most of the over 183,000 ounces of placer gold mined from the region since 1898 (Foley and Summers, 1990; Newberry and others, 2010; Athey and others, in preparation). Subsequent crustal shortening places Mesozoic and Paleozoic bedrock over Cenozoic basin strata at several locations along the MSCFS, either as a single thrust sheet or successive imbricates. High-angle contractional faults, such as the McCallum Creek fault in the HoodoosGakona area where it places the exhumed Eocene basin over late Miocene to Pleistocene(?) strata, reactivate former extensional structures and therefore constitute a different structural style that may be contemporaneous with low-angle thrusting, but in some cases appears to post-date it based on local dissection of the thrust sheets.

The relation between low-angle thrust faults oriented at acute angles to the strike-slip Denali fault and higher angle reverse faults that reactivate sub-parallel extensional faults is consistent with a simple- or oblique-shear model in a dextral system. In this scenario, shallow-dipping faults at higher angles to the convergence direction accommodate the greatest magnitude of shortening, and oblique contraction is favored on steeper faults oriented at lower angles to the greatest principal stress (Sanderson and Marchini, 1984). These geometrical observations agree in principle with fault plane slip data of Waldien and others (2018). That study was able to delineate that there was a greater component of strike-slip on fault segments oriented at lower angles to the inferred convergence vector. Thus, structures composing the MSCFS may serve as scaled examples of how strain is distributed south of Denali fault system. If this is the case, then low-angle contractional faults of the MSCFS would be analogous to other structures to the west, including the Broxson Gulch (Waldien and Roeske, 2017), Susitna Glacier (Riccio and others, 2014), and the proposed Broad Pass fault (Haeussler and others, 2017). These thrusts, lying to the west of the MCSCS, all splay southwestward off the Denali fault, where as much as 12.5 miles $(20 \mathrm{~km})$ of strike-slip may be lost to shortening along a single structure (for instance, the Broxson Gulch fault, Waldien and others, 2017).

The preliminary interpretations presented here will be refined and details change as the map relationships and structural data are more carefully assessed and integrated with the stratigraphic observations, stratigraphic, volcanic, and provenances ages, and thermochronology data. Identifying multiple structural styles along the MSCFS and resolving their temporal and spatial relationships is an important first step to understanding how strain evolved with long-term slip along the Denali-Totschunda fault system. The new results will provide insights into how proposed releasing and restraining bends along the system might have controlled deformation in the adjacent crust that contributed to growth of the eastern Alaska Range and subsidence at the northern extent of the Copper River basin. In addition, this research may constrain systematic changes in the regional stress field during Cenozoic time. This study demonstrates how collaborations between the Alaska Department of Natural Resources and academic institutions to explore scientific questions can result in a better understanding of the geologic systems that control the state's natural resource occurrences. The geologic mapping conducted over several field seasons summarized here will be compiled and integrated with collaborative stratigraphic, geochronologic, and thermochronologic results from the MSCFS for publication as one or more peer-reviewed journals articles. The 1:25,000-scale digital map compilation and database will be published as downloadable ArcGIS files through the DGGS online library. 


\section{ACKNOWLEDGMENTS}

Field mapping was made possible by a National Science Foundation grant to Ridgway (Purdue University), Benowitz (University of Alaska Fairbanks) and Fitzgerald (EAR-1550034, Syracuse University). We thank Quintin Slade, 40-Mile Air and Alaska Land Exploration for air charter services. Local insights from miners Ron, John, and Jeff Hoffman during our field activities were helpful and appreciated. We benefited from discussions with Trevor Waldien, Sarah Roeske, Jennifer Athey, Kailyn Davis, Thomas Warfel, Gerard Otiniano, and Ann Blythe. Reviews by Jennifer Athey and Trevor Waldien improved the manuscript.

\section{REFERENCES}

Allen, W.K., Ridgway, K.D., Benowitz, J.A., Waldien, T.S., and Roeske, S.M., 2015, Neogene transpressional basin development along the Denali fault system in the eastern Alaska Range: the stratigraphy of the McCallum basin and implications for displacement along the Denali fault system, Geological Society of America Abstracts with Programs.v. 46, no. 6, p. 364.

Allen, W.K., Ridgway, K.D., Benowitz, J.A., Waldien, T.S., and Roeske, S.M., 2016, Sedimentary and volcanic record of Neogene transpressional foreland basin development along the central Denali fault system, eastern Alaska Range, Geological Society of America Abstracts with Programs. v. 48, no. 7. http://doi.org/10.1130/abs/2016AM-284817

Allen, W.K., Ridgway, K.D., Benowitz, J.A., Fasulo, C., Keough, B.M., Warfel, T.S., Fitzgerald, P.G., Gillis, RJ,, and Trop, M.J.,2018, Cenozoic basin development and strike-slip displacement along the Denali fault system, eastern Alaska Range, Alaska: A provenance approach, Geological Society of America Abstracts with Programs. Athey, J.E., Hults, C.P., Freeman, L.K., Szumigala, D.J., Werdon, M.B., and Koehler, RD., in preparation, Bedrock geologic map of the Slate Creek area, Chistochina mining district, Mount Hayes Quadrangle, Alaska, Alaska Division of Geological \& Geophysical Surveys Report of Investigation.

Benowitz, J.A., Vasant, G., Roeske, S., Layer, P.L., Hults, C., and O'Sullivan, PB., 2012, Eocene to present slip rate on the Denali fault system, American Geophysical Union Annual Meeting, San Francisco, CA. Dec. 3-7.

Bond, G.C., 1976, Geology of the Rainbow Mountain - Gulkana Glacier area, eastern Alaska Range, with emphasis on upper Paleozoic strata: Alaska Division of Geological \& Geophysical Surveys Geologic Report 45, 47 p., 3 sheets. http://doi.org/10.14509/373

Fitzgerald, P.G., Roeske, S.M., Benowitz, J.A., Riccio, S.J., Perry, S.E., and Armstrong, P.A., 2014, Alternating asymmetric topography of the Alaska range along the strike-slip Denali fault: Strain partitioning and lithospheric control across a terrane suture zone: Tectonics, v. 33, no. 8, p. 1,519-1,533.

http://doi.org//10.1002/2013TC003432

Fitzgerald, P.G., Benowitz, J.A., Ridgway, K.D., Warfel, T.S., and Allen, W.K., 2017, The role of terrane rheology vs. fault geometry for mountain formation and exhumation along the Denali fault of south-central Alaska: Geological Society of America Abstracts with Programs, v. 49, no. 6. https://doi.org/10.1130/abs/2017AM$\underline{305797}$

Foley, J.Y., and Summers, C.A., 1990, Source and bedrock distribution of gold and platinum-group metals in the Slate Creek Area, northern Chistochina mining district, east-central Alaska: U.S. Bureau of Mines Open-File Report 14-90,49 p., 1 sheet, scale 1:31,680. 
Haeussler, P.J., Matmon, A., Schwartz, D.P., and Seitz, G.G., 2017, Neotectonics of interior Alaska and the late Quaternary slip rate along the Denali fault system: Geosphere, v. 13, p. 1,445-1,463.

http://doi.org/10.1130/GES01447.1

Hanson, L.G., 1963, Bedrock geology of the Rainbow Mountain area, Alaska Range, Alaska: Alaska Division of Mines and Minerals Geologic Report 2, 82 p., 2 sheets. http://doi.org/10.14509/331

Newberry, RJ., Athey, J.E., and Foley, J.Y., 2010, Placer Au-Pt-Cu-Hg from the Slate Creek area, east-central Alaska Range: mixed, shaken, baked, and regurgitated, Alaska Miners Association 2010 Annual Convention, Anchorage, Alaska, November 1-7, 2010.

Nokleberg, W.J., Aleinikoff, J.N., Bond, G.C., Ferrians, O.J., Jr., Herzon, P.L., Lange, I.M., Miyaoka, RT., Richter, D.H., Schwab, C.E., Silva, S.R., Smith, T.E., and Zehner, R.E., 2015, Geologic maps of the eastern Alaska Range, Alaska (44 quadrangles, 1:63,360 scale), with descriptions and interpretations of map units: Alaska Division of Geological \& Geophysical Surveys Report of Investigation 2015-6, 64 p., 45 sheets, scale 1:63,360. http://doi.org/10.14509/29444

Ratchkovski, N.A., 2003, Change in stress directions along the central Denali fault, Alaska after the 2002 earthquake sequence, Geophysical research letters, v. 30, n. 19.

Riccio, S.J., P.G. Fitzgerald, J.A. Benowitz, and S.M. Roeske, 2014, The role of thrust and strike-slip faulting in the formation of the Alaska Range: thermochronological constraints from the Susitna Glacier thrust fault region of the Denali fault system. Tectonics, v. 33, no. 11. http://doi.org/10.1002/2014TC003646

Rose, A.W., 1967, Geology of the upper Chistochina River area, Mt. Hayes Quadrangle, Alaska: Alaska Division of Mines and Minerals Geologic Report 28, 41 p., 2 sheets, scale 1:40,000. http://doi.org/10.14509/357

Sanderson, D.J., and Marchini, W.RD., 1984, Transpression, Journal of Structural Geology, v. 6, no. 5, p. 449-458.

Waldien, T.S., Roeske, S.M., Allen, W.K., Ridgway, K.D., Benowitz, J.A., 2015, Oblique thrust faulting and foreland basin deformation in a strike-slip fault system, eastern Alaska Range, Alaska, Geological Society of America Abstracts with Programs. v. 46, no. 6, p. 364.

Waldien, T.S., and Roeske, S.M., 2017, Geologic map of Broxson Gulch, eastern Alaska Range, Alaska, Geological Society of America Abstracts with Programs. v. 49, no. 6. http://doi.org/10.1130/abs/2017AM-307860

Waldien, T.S., Roeske, S.M., Benowitz, J.A., and Stockli, D.F., 2017, Cenozoic reactivation of Cretaceous terrane accretionary structures in the eastern Alaska Range, Alaska: Geological Society of America Abstracts with Programs, v. 49, no. 6. https://doi.org/10.1130/abs/2017AM-307791

Waldien, T.S., Roeske, S.M., Benowitz, J.A., Allen, W.K., Ridgway, K.D., 2018, Late Miocene to Quaternary evolution of the McCallum Creek thrust system, Alaska: Insights for range-bounding thrusts in transpressional orogens: Geosphere, v. 14, no. 6, p. 2,379-2406.

Warfel, T.S., Fitzgerald, P.G., Benowitz, J.A., Ridgway, K.D., and Allen, W.K., 2018, Low temperature thermochronology constraints on exhumation along and across the east-central Denali fault system, Geological Society of America Abstracts with Programs. Vol. 50, No. 2. http://doi.org/10.1130/abs/2018NE-310989 